
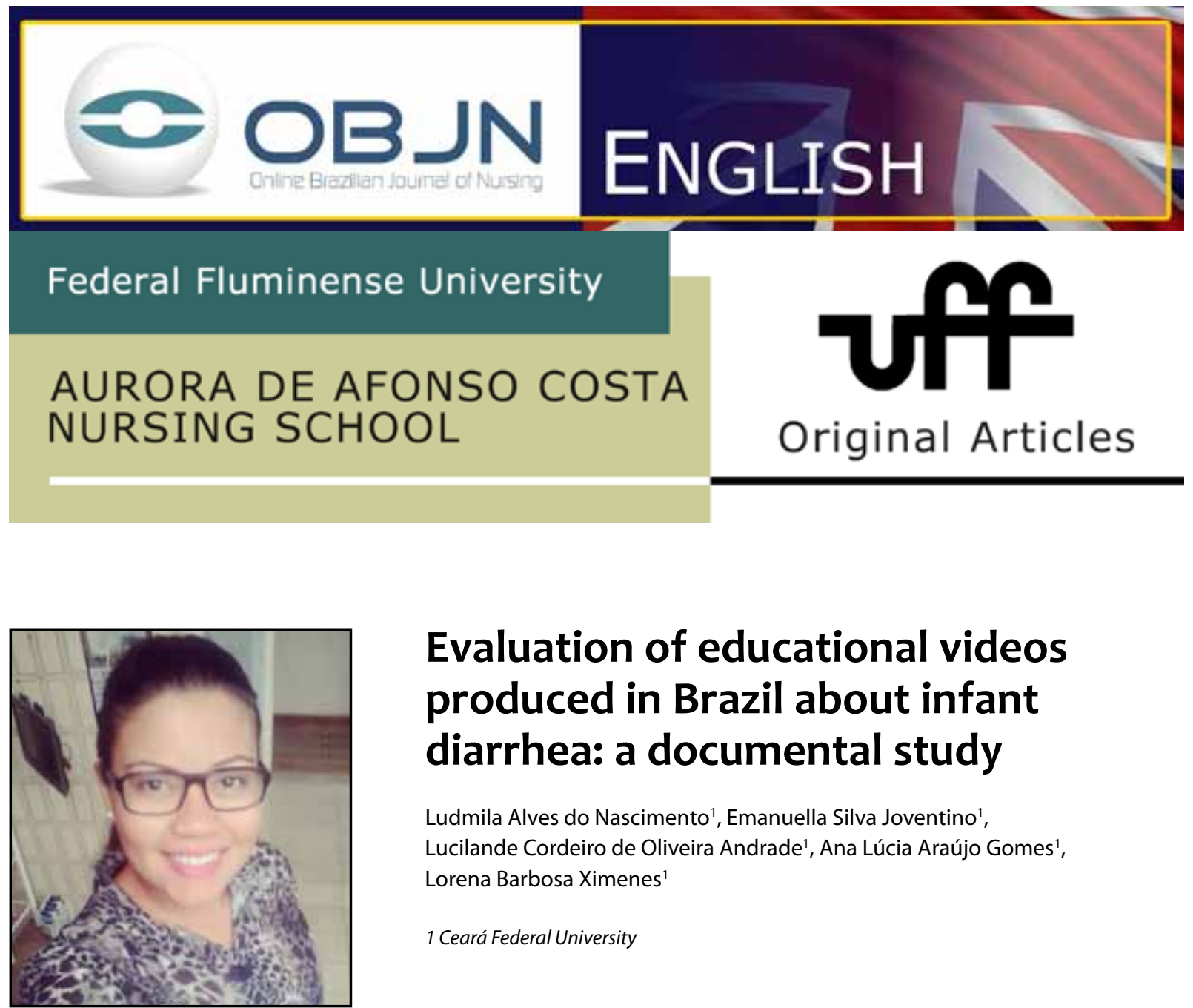

\title{
Evaluation of educational videos produced in Brazil about infant diarrhea: a documental study
}

\author{
Ludmila Alves do Nascimento', Emanuella Silva Joventino', \\ Lucilande Cordeiro de Oliveira Andrade'1, Ana Lúcia Araújo Gomes', \\ Lorena Barbosa Ximenes' \\ 1 Ceará Federal University
}

\section{ABSTRACT}

Aim: to characterize and evaluate educational videos produced in Brazil that deal with the aspects related to the prevention and/or management of infant diarrhea. Method: this is a documental study which evaluated 25 educational videos in terms of their content and the technical information they contained. Results: it was observed that $60 \%$ of the videos were produced in the 1990 s and none were adapted for the hearing-impaired. With regard to their pathological preventive steps, 52\% mentioned the treatment of drinkable water, and $48 \%$ mentioned the washing of hands. Breastfeeding was mentioned in $80 \%$ of the videos as a protective measure against the aggravation of the health issue. Maternal self-efficiency to prevent infant diarrhea was present in $28 \%$ of the sample. The production of the videos analyzed occurred mainly during the 1990 s, due to an intense movement to reduce significantly infant mortality in Brazil at that time. Conclusion: the need to produce new videos related to the topic, including self-efficiency within the context of the prevention of infant diarrhea was confirmed.

Descriptors: Diarrhea, Infantile; Educational Films and Videos; Self Efficacy; Child Health. 


\section{INTRODUCTION}

Infant mortality is recognized as an indicator of the life and health conditions of a society, and one of the Millennium Development Goals (MDG) is to reduce it. For such an achievement, it is important to deal simultaneously with the prevention and the treatment of infectious diseases ${ }^{(1)}$.

In this context, infant diarrhea is a common manifestation generated by infectious and parasitic illnesses, which persists as a relevant public health issue as one of the main causes of consultations, hospitalization and mortality of children under five years of age ${ }^{(2)}$.

In developing countries, diarrhea affects around 1.3 billion children below five years of age annually, especially those individuals under one year old ${ }^{(3)}$.

Despite Brazil having achieved significant development in the prevention and control of infectious diseases with the implementation of basic sanitation policies, acute diarrheic illnesses still present high levels of incidence. In 2011, in the Brazilian state of Ceará, there were 118,361 cases of diarrhea in children below two years of age and, from those, 93 deaths. With regard to children below five years of age, there were 2,918 hospitalizations and, among those, six deaths ${ }^{(4)}$.

In Brazil, based on this reality, methods have been used to promote infant health, the adoption of control measures, assisting health promotion steps and behavior, and, as a consequence, the prevention of diarrhea ${ }^{(3)}$. Among the above-mentioned steps, it is possible to list some such as: the Breastfeed and Nurture Brazil Strategy (Estratégia Amamenta e Alimenta Brasil in Portuguese); the Integrated Care of Prevailing Diseases during Childhood (AIDPI, in Portuguese); the access to vaccination against rotavirus (available from the Brazilian Unified Health System - SUS, in Portuguese - covering 91.24\% of the country); the Brazilian National Policy for Proper Nutrition, included into the Brazilian Food and Nutrition Security Plan; and the Brazilian National Health Policy, with decentralization, infiltration into various areas, and ease of access for people to the system ${ }^{(5)}$.

Together with these strategies and policies, there is a need to deal with the workplaces of the professionals through training in health. One aspect of this is that the nurse can use as much technology available such as light technologies. The policy clearly states that the implementation of care requires the creation of relationships such as bonds, service management, and being welcoming. In terms of light-hard technologies these are based on well-known information (theories, care models, and nursing processes); while in the case of hard technologies, it uses instruments, standards and technological equipment (6). Therefore, the educational video deserves attention as an example of hard technology that can be used in primary, secondary, and tertiary care. It is a ludic learning tactical approach that, as it provides a quick spread of information, can easily be made available to any person, independently of his social and/or educational level ${ }^{(7)}$.

Based on such prerogatives, the following question arose: which characteristics are seen on Brazilian videos that deal with the aspects related to prevention and/or management of infant diarrhea? Within this context, it is expected that this study will be able to support nurses when it comes to developing new teaching-learning strategies and educational videos, as well as using them during their educational tasks, when working to promote health, and particularly the prevention and management of diarrhea.

Therefore, this present study aimed to characterize and evaluate Brazilian educational videos that deal with the aspects related to the prevention and/or management of infant diarrhea. 


\section{METHOD}

This is a piece of documentary research, which was divided in terms of the following steps: survey of available videos in previously selected institutions, based on the availability of their catalogs on the Internet; the selection of videos; the completion of the proposed instrument for evaluation; an analysis of the videos; and a synthesis of the results.

The data was acquired through an active search, between March and June 2012, through a reading of the synopses of the available videos described in the video catalogues of the Oswaldo Cruz Foundation (FIOCRUZ, in Portuguese) $)^{(8)}$ of the Rio de Janeiro Federal University (UFRJ, in Portuguese), and of the Ceará Federal University (UFC, in Portuguese). We opted to use these institutions because they are significantly important in Brazil in terms of producing audiovisual materials, and also because these institutions publish their video catalogues online. As criteria for the inclusion of videos, we opted to select the ones that dealt with aspects related to prevention and/or management of infant diarrhea, such as hygiene, treatment of drinkable water, breastfeeding, vaccination, basic sanitation, and rehydration therapies, in that they are all considered to be essential measures to prevent and treat infant diarrhea ${ }^{(9)}$.

After the survey, each video was watched at least three times by two researchers on separate occasions, in an attempt to minimize possible bias during the evaluation of the videos. The first visualization of the video was performed with the intention of observing its compatibility with the chosen criteria for inclusion. During the second occasion, each video was watched non-stop in order to understand the whole video; the third time (or more) it was watched with pauses, in order to complete the instrument of analysis.

This instrument was built by the authors and submitted to the scrutiny of two other researchers in the area. Such scrutiny included technical information about the video (title, producer, year, source, duration, target group, language, type of video, and focus), and information regarding the content (concept of diarrhea, epidemiological aspects, steps of treatment and mentioned preventions of infant diarrhea, and the support to maternal self-efficiency).

The data gathered was analyzed through the use of descriptive statistics, using the Statistical Package for the Social Sciences (SPSS) software, version 17.0. The results found were presented in sheets and tables, analyzed in the light of the relevant literature.

With regard to the ethical aspects, according to the standards established by the Brazilian National Council for Ethics in Research (CONEP, in Portuguese), the documentary studies need a declaration of approval. However, as this study was performed with regard to videos, based on catalogues that are available through simple Internet access, it was exempt from the need for approval from the Committee. All documentation, payments, and requests to acquire the videos were followed.

\section{RESULTS}

With regard to the 25 videos described in Chart 1, it can be seen that 20 of them were found on the FIOCRUZ video catalogue; four came from UFRJ, available according for shipping to the address provided by the institution; and one video from UFC, found during an in-person search of the resources of that institution. The movies dealt directly or indirectly with topics related to the prevention and/or management of infant diarrhea: children's health, prevention of parasitic diseases, hygiene, infant diarrhea, breastfee- 
Chart 1 - Distribution of videos evaluated according to the institutions - FIOCRUZ, UFRJ and UFC. Fortaleza, Brazil, 2012.

\begin{tabular}{|l|l|l|l|l|}
\hline \multicolumn{1}{|c|}{ Title of the video } & \multicolumn{1}{|c|}{ Production } & \multicolumn{1}{c|}{ Souce } & \multicolumn{1}{c|}{ Year } \\
\hline 1 & Saúde da criança & COOPAS/TVE & FIOCRUZ & 2006 \\
\hline 2 & Aleitamento materno e diarreia & NVT/CICT/FIOCRUZ & FIOCRUZ & 1992 \\
\hline 3 & $\begin{array}{l}\text { Ações de saúde sobre a saúde da mulher e da } \\
\text { criança }\end{array}$ & TAS VÍDEO PRODUÇÕES & FIOCRUZ & 1994 \\
\hline 4 & Visitantes indesejados & FHDF & FIOCRUZ & 1997 \\
\hline 5 & $\begin{array}{l}\text { A saúde em rede contra os surtos: diarreia e } \\
\text { outros sintomas de contaminação }\end{array}$ & $\begin{array}{l}\text { ARGUMENTO- UNIDADE DE DO- } \\
\text { ENÇAS DE VEICUKAÇÃO HÍDRICA E } \\
\text { ALIMENTAR- SVS/MS }\end{array}$ & FIOCRUZ & 2010 \\
\hline 6 & Aleitamento materno & MAKRONPRODUÇÕES LTDA & \\
\hline 7 & Sem o bicho no bucho & ETAPAS VÍDEOS & FIOCRUZ & 1994 \\
\hline 8 & Diarreia e ira & MADE TO CREATE & FIOCRUZ & 2001 \\
\hline 9 & Higiene corporal & FUNDAJ & FIOCRUZ & 1997 \\
\hline 10 & El uso de la terapia de rehidratacion & TELEREY S.A & FIOCRUZ & 1994 \\
\hline 11 & $\begin{array}{l}\text { Lactância materna: como proteger um recurso } \\
\text { natural }\end{array}$ & OPS/UNICEF & FIOCRUZ & 1987 \\
\hline 12 & Saúde sim, cólera não & CTE-UERJ/NUTES/UFRJ/FIOCRUZ & FIOCRUZ & 1990 \\
\hline 13 & Saúde da criança & $\begin{array}{l}\text { EMATER/SEAB/ESCOLA PÚBLICA DE } \\
\text { SAÚDE/SESA/ISEP }\end{array}$ & FIOCRUZ & 1993 \\
\hline 14 & Desnutrição infantil & NECC/FACHA & 1994 \\
\hline 15 & Esta receita vale uma vida & $\begin{array}{l}\text { CENTRO NACIONAL DE PRODUÇÃO } \\
\text { DE TELEVISÃO/SENAC }\end{array}$ & FIOCRUZ & - \\
\hline 16 & & O recém-nascido & MADE TO CREATE & 1990 \\
\hline 17 & Caravana da saúde & ZARATANA PRODUÇÕES LTDA & FIOCRUZ & 1997 \\
\hline 18 & Amos acabar com a diarreia & $\begin{array}{l}\text { SES-PERNAMBUCO/FNS-PERNAM- } \\
\text { BUCO }\end{array}$ & FIOCRUZ & 1994 \\
\hline 19 & Educação para a saúde & FRP/TVE/MEC & 1996 \\
\hline 20 & Vacinação & MADE TO CREATE & FIOCRUZ & 1992 \\
\hline 21 & $\begin{array}{l}\text { Doenças diarreicas: higiene é a melhor foema de } \\
\text { prevenção }\end{array}$ & - & FIOCRUZ & 1997 \\
\hline 22 & Amamentação: vamos recuperar esta prática & NUTES/UFRJ & UFC & - \\
\hline 23 & Diarreia: arma que fere e mata & NUTES/UFRJ & UFRJ & 1987 \\
\hline 24 & Criança brasileira, condições de saúde. & NUTES/UFRJ & UFRJ & 1987 \\
\hline 25 & Hidratação oral & NUTES/UFRJ & UFRJ & 1987 \\
\hline & & & UFRJ & 1982 \\
\hline
\end{tabular}

ding, infant vaccination, and oral rehydration therapy. From the analyzed videos, it is also possible to determine that the production of such material was done between 1982 and 2010 , with the participation of various public and/or private institutions (Chart 1).

According to Table 1, it can be seen that 15 videos (60\%) were produced during the 1990s; $10(76 \%)$ of them were short films, varying from two to 20 minutes in length. With regard to the type of image, it can be seen that 23 (92\%) of the videos used real images or, in other words, using real actors and real scenarios. In addition, $15(60 \%)$ also used textual information, but none had subtitles for the hearing impaired. It was clear that $15(51.7 \%)$ of the videos were aimed at families, 15 (62.5\%) of the sample demonstrated the opinions of lay people, and $19(76 \%)$ included the opinions of health professionals.

The main preventive steps against infant diarrhea that were mentioned are described in Table 2. Therefore, it can be seen that 20 $(80 \%)$ of the videos focused on breastfeeding 
as a preventive step against diarrhea; 13 (52\%) preferred to mention the treatment of drinkable water; 12 (48\%) dealt with hand washing; and 11 (44\%), general vaccination. Only one video (4\%) mentioned the use of vaccination against Human Rotavirus. Basic sanitation was the topic discussed in 10 (40\%) of the videos.

Table 1- Distribution of the sample according to the year of production and the technical characteristics of the videos. Fortaleza, Brazil, 2012.

\begin{tabular}{lcc}
\hline \multicolumn{1}{c}{ Variables } & $\mathbf{n}$ & $\%$ \\
\hline Year & 5 & 20 \\
\hline$<1989$ & 15 & 60 \\
$1990-1999$ & 3 & 12 \\
$>2000$ & 2 & 8 \\
Not informed & & \\
\hline Length of the video & 19 & 76 \\
\hline From 2 to 20 minutes & 6 & 24 \\
$>20$ minutes & 5 & 20 \\
\hline Format of the video & 20 & 80 \\
\hline Television show & & \\
Educational & 23 & 92 \\
\hline Type of images in the video & 2 & 8 \\
\hline Real images & 15 \\
Real images and cartoons & 60 \\
\hline Does it have textual information? & 10 \\
\hline Yes & 40 \\
\hline No
\end{tabular}

Does it have subtitles for the hearing impaired? Yes

\begin{tabular}{lcc} 
No & 25 & 100 \\
\hline Target audience & 12 & 41.4 \\
\hline Professionals & 1 & 3.4 \\
Children & 15 & 51.7 \\
Family & 1 & 3.4 \\
Others & 15 & 62.5 \\
\hline Does it have the opinion of lay people? & \\
\hline Yes & 10 & 37.5 \\
No & 19 & 76 \\
\hline Does it have the opinion of professionals? \\
Yes & 6 & 24 \\
\hline
\end{tabular}

Table 2- Distribution of preventive measures for infant diarrhea mentioned in the videos. Fortaleza, Brazil, 2012.

\begin{tabular}{|c|c|c|}
\hline Variables & $\mathbf{n}$ & $\%$ \\
\hline \multicolumn{3}{|l|}{ Prevention $(n=25)$} \\
\hline Hand washing & 12 & 48 \\
\hline Washing of food & 7 & 28 \\
\hline $\begin{array}{l}\text { Washing of nursing bottles and paci- } \\
\text { fiers }\end{array}$ & 1 & 4 \\
\hline Washing of household utensils & 3 & 12 \\
\hline Treatment of drinkable water & 13 & 52 \\
\hline $\begin{array}{l}\text { Protection of feed/water against } \\
\text { instects }\end{array}$ & 3 & 12 \\
\hline Follow up in health care units & 6 & 24 \\
\hline Breastfeeding & 20 & 80 \\
\hline $\begin{array}{l}\text { Use of soap bars during personal } \\
\text { hygiene moments }\end{array}$ & 6 & 24 \\
\hline Vaccination, in general & 11 & 44 \\
\hline Vaccination against Human Rotavirus & 1 & 4 \\
\hline Quality of nutrition for children & 9 & 36 \\
\hline $\begin{array}{l}\text { Full contact of the child with the floor/ } \\
\text { barefoot children }\end{array}$ & 1 & 4 \\
\hline Basic sanitation & 10 & 40 \\
\hline \multicolumn{3}{|l|}{ Management $(n=25)$} \\
\hline Homemade oral rehydration solution & 9 & 36 \\
\hline Oral rehydration therapy & 9 & 36 \\
\hline Nutrition while in diarrhea & 10 & 40 \\
\hline Drinking while in diarrhea & 7 & 28 \\
\hline Use of non-prescribed medication & 2 & 8 \\
\hline Use of precribed medication & 3 & 12 \\
\hline Observation of diuresis & 3 & 12 \\
\hline Parenteral therapy (IV) & 3 & 12 \\
\hline
\end{tabular}

\section{DISCUSSION}

The largest production of the Brazilian movies occurred during the 1990s and related to the studied topic. This was due to an intense nationwide mobilization to reduce infant mortality. During this decade, efforts were focused on fighting against infectious diseases and malnutrition ${ }^{(10)}$.

The findings of this research regarding the duration of the movies demonstrate that, in general, movies created to educate society as a whole are short movies, especially those produced by the Brazilian Ministry of Health ${ }^{(11)}$. 
However, some studies demonstrate that videos which lasts less than 10 minutes do not allow an adequate discussion of the topic. In addition, videos lasting more than 20 minutes can bore the learners, which makes it difficult to learn anything ${ }^{(7,12)}$.

The findings of this present study corroborate that of a piece of research that characterized videos produced in Brazil about sexually transmitted diseases (STDs), the majority of which were between 10 to 19 minutes in duration (12). Other educational videos, with lengths of between 10 and 20 minutes, achieved positive results regarding the promotion of the health of children, such as promoting social abilities in pre-school children (12 minutes) ${ }^{(7)}$; a film produced in the United States of America, to provide information, reliability and satisfaction to parents when evaluating fever in their own children; another American movie that taught the necessary abilities for self-protection on the part of children ${ }^{(13)}$.

It is possible to observe that, from all the videos analyzed, the narrator was the main character, emphasizing the goal of increasing interaction with the viewer. However, there was an attempt to use other resources, such as characters and textual information, to provide a more ludic and less tiring learning experience ${ }^{(12)}$.

The movies, in general, used real scenarios - which have been one of the many alternatives in this type of educational technology, instead of simulations of reality. The real images help to bring the viewer closer to the topic discussed in the movie, thus allowing the families to identify with what they are watching, and believing that they are capable of preventing and treating infant diarrhea, despite the issues faced everyday.

Some movies showed mothers during breastfeeding, or with children suffering from diarrheic illnesses, showing their opinions regarding the topic. These images are a positive influence when it comes to promoting healthy behavior. According to Brandura ${ }^{(14)}$, modeling - or in other words, providing examples from a third party - is a relevant source when it comes to generating self-efficiency. It is important to highlight that self-efficiency was not the center of attention of the movies, as the majority of them illustrated what mothers should know (risk factors and adopted steps) to prevent the illness.

Another point to call attention to is that the information alone that mothers have is not enough. They must also adopt healthy behavior standards. Hence, the movies must deal not only with the recognition of the risk factors related to infant diarrhea, but also to reinforce positive behavior and the motivation of the mothers. When they believe they are capable of keeping their children healthy, they will be more inclined to perform the most adequate steps to avoid diarrhea, even if the information regarding the issue is not accurate ${ }^{(15)}$.

Based on that, it is possible to conclude that the movies must work as strategies related to teaching and learning, stimulating critical thinking, and to develop, in the families, the competencies, abilities, and self-efficiency needed so they can work in terms of the reality that surrounds their families. According to the Brazilian national strategy entitled Integrated Care to the Prevailing Diseases in Childhood (AIDPI, in Portuguese), every child must live in a social context that is constantly developing, and the family should have its internal practices improved as caregiver and the main promoter of infant health ${ }^{(1)}$.

In terms of the language used in the videos, two main types of discourse, as described by Rondelli ${ }^{(16)}$ were noted: the lay and the specialist. We emphasize that both are extremely important when it comes to improving learning, based on the fact that the first represents the population, the way it thinks and behaves regarding the 
caring practices with regard to prevent diarrhea; the second is the technical-scientific language of the health professional, giving credit and bringing awareness to those watching the movie.

An element that was not observed in the videos in this study was the accessibility of information to the hearing impaired. It is known that one of the guiding and dominating proposals is Special Education. This consists of the integration of people with disabilities into the educational process as they are also citizens, with rights and duties towards society as a whole.

Considering that the educational videos selected for the sample did not specifically demonstrate the prevention of infant diarrhea, it was seen that they dealt with related topics of prevention or protection, which are breastfeeding and hygiene. Therefore, these are the main thematic areas.

Breastfeeding was mentioned in $80 \%$ of the videos, in a clear and comprehensible way, as it is an element of natural and well-known protection against infant diarrhea; as well as the stimulus for the participation of the families in the process of breastfeeding, considered as being a positive step in terms of prevention ${ }^{(17)}$. Other studies demonstrate that children that present a higher number of diarrheic episodes had stopped being breastfed before the sixth month of their lives and that nurslings that lived in poorer areas face a higher risk of acquiring intestinal infections during weaning, due to contact with contaminated water and food ${ }^{(18)}$.

Infant hygiene was vaguely mentioned and, in a few videos, it was even recognized that infant and domestic hygiene is needed to prevent infant diarrhea. It is a topic that should be emphasized more in the educational movies produced, as inefficiency and insecurity while caring for children in terms of proper habits of personal hygiene can be related to the sickening of such children ${ }^{(9)}$.
When discussing the health of children in a general sense, some movies were identified as dealing with the main risk factors for infant illness, as well as vaccinations, prevention and the treatment of diarrheic and helminthic diseases (which are, most of the time, the sources of diarrhea in children).

The fact that one video deals with vaccination against human rotavirus as a positive factor when it comes to preventing infant diarrhea, can be explained by the fact that the large majority of the movies was produced before 1999. This period is prior to the inclusion of vaccination against rotavirus in the Brazilian national vaccination calendar, which occurred only after $2006^{(19)}$. With such information, it is important to highlight the production of more up-to-date movies, making use of better approaches when discussing the topic, with the aim of diminishing the illness.

With regard to the videos that had diarrhea as the main topic, it is possible to see the use of epidemiological data, the definition of the disease, and recommendations with regards to prevention and management, to explain to the general public the details of the topic.

The occurrences of diarrheic pathologies are associated with the socioeconomic status of the infected individuals, to vaccination, and to inadequate nutrition. Hence, when health services are guaranteed access to the whole of society, it can help the adoption of behavior that impacts on the health situation and to the autonomy of people in terms of the determinatives and conditions of health of the collectivity. The use of caring technologies can help in the management of demands and with regard to the higher frequency of health needs, and the relevance in the territory in which people live and relate to each other ${ }^{(1)}$.

Based on this data, the importance of motivating breastfeeding can be observed when 
it comes to reducing the incidence of infant diarrhea. However, it can also be seen that there is a need to demonstrate other essential actions related to this type of prevention, such as the follow-up of children by health professionals; proper hygiene with regard to domestic utensils; proper hand washing, especially when handling food; correct disposal of household waste; environmental hygiene, with a special attention to intra-household contact with domestic pets, recreational activities, or showering using suspicious water ${ }^{(20)}$. These aspects, once discussed, can become part of the context experienced by the viewers, allowing them to identify themselves in terms of the proposed topics, especially in communities seen to be at higher risk and to be particularly vulnerable.

Bringing up the reality of infant diarrhea as a topic for discussion can stimulate the participation of caregivers, making them reflect upon the fact that such an infirmity has a significant family and social impact, for them to demand a "task force" to control them, and making them aware that each member has an active role. Therefore, it is imperative that nurses use them as part of a teaching-learning strategy, an instrument that permits them to amplify the autonomy and the capacity of families in their caring role and in facing the determinants and conditions with regard to good health.

\section{CONCLUSION}

The result of this study showed both positive aspects and some gaps in the production of educational videos that discuss the aspects related to the prevention or to the management of infant diarrhea. It also showed the need to produce new set of resources, with topics and approaches more directly focused on preventing infant diarrhea, and that includes a wider and more effective spectrum for caring in terms of promoting children and family health, based on self-efficiency.

According to the analysis, based on the educational videos produced in Brazil about the prevention of infant diarrhea, the importance of an innovative approach on the part of the nurse can be seen, permitting a more significant learning process. This motivates the public to seek more information in order to transform their own life habits. It is also an essential instrument for the health professional who also works as an educator; a resource that is practical and easily handled.

One of the limitations of this study is the lack of availability of all the movies produced in Brazil on the topic; even though the catalogues are easily found online, some have limited access. Another issue was the VHS format of some of the videos, which generated, on occasions, problems with regard to understanding the images and the audio.

Despite this, it was possible to see that many videos did not relate specifically to the topic of this study - infant diarrhea - demonstrating the need to produce more updated and specifically related topics regarding dealing with this disease.

It is important to note that movies are an educational resource that is complementary to teaching. This means that they are not efficient without the intervention of the nurse as part of this process. The professional must work as a guide to the parents or guardians of the children, aiming to reinforce the message transmitted by the video, and facilitating the learning process.

There is also an important issue to call attention to. This is that educational videos permit an adequate exchange of knowledge regarding infant diarrhea; they permit the creation of a favorable environment to empower families in order to promote infant health and support all 
involved in the process of caring. It is also implied that the use of the theory of self-efficiency has been evaluated in terms of the videos produced about the management and prevention of infant diarrhea which cannot portray the topic in a specific way. For this reason, we declare the need to perform further studies that deal with self-efficiency in the development of educational videos to prevent infant diarrhea.

\section{REFERENCES}

1. Ministério da Saúde (Brasil). Secretaria de Atenção à Saúde, Departamento de Ações Programáticas e Estratégicas. Manual AIDPI neonatal. 3. ed. Brasília : Ministério da Saúde; 2012.

2. Oliveira T, Latorre M. Trends in hospital admission and infant mortality from diarrhea: Brazil, 19952005. Rev Saúde Pública [internet]. 2010 Fev [Cited 2014 Mar 8] 44(1). Available from: http:// www.scielosp.org/scielo.php?script=sci_ar ttext\&pid=S003489102010000100011\&lng $=$ en. DOI: http://dx.doi.org/10.1590/S003489102010000100011.

3. World Health Organization (Switzerland). Diarrhoea: why children are still dying and what can be done. 2009 [cited 2012 june 19]. Available from: http://whqlibdoc.who.int/publications/2009/9789241598415_eng.pdf.

4. Ministério da Saúde (Brasil). Morbidade hospitalar do SUS- por local de internação- Ceará, 2011. Fortaleza: Ministério da Saúde; 2011. [Cited 2009 Jan 11] Available from: <http://portal.saude.gov. $\mathrm{br} /$ portal/arquivos/pdf/nota_iriri.pdf $>$.

5. Brasil. Secretaria De Políticas De Saúde. 2013. [Cited 2014 Mar 8]. Available from:bvsms.saude. gov.br/bvs/publicacoes/pnan.

6. Merhy, EE, Onoko R. Agir em saúde: um desafio para o público. São Paulo: Hucitec; 2007.

7. Moraes, A. F. Cultural diversity in health-related videos. Interface - Comunicação, Saúde, Educação [internet]. 2008 Dec [Cited 2014 Mar 8] 12(27). Available from: http://www.scielo. $\mathrm{br} /$ scielo.php?script=sci_arttext\&pid=S1414-32832008000400011\&lng=en. DOI: http://
dx.doi.org/10.1590/S141432832008000400011.

8. Ministério da Saúde (Brasil). Instituto de Comunicação e Informação Científica e Tecnológica em Saúde Serviço de Produção e Distribuição em Audiovisuais em Saúde. Rio de Janeiro: Ministério da Saúde; 2008. [cited 2014 Mar 8] Available from: http://portal.fiocruz.br/pt-br/ tags/videosa\%C3\%BAde-distribuidora.

9. Ministério da Saúde (Brasil). Secretaria de Vigilância em Saúde. Departamento de Vigilância Epidemiológica. Guia de vigilância epidemiológica / Ministério da Saúde, Secretaria de Vigilância em Saúde, Departamento de Vigilância Epidemiológica. 7. ed. Brasília : Ministério da Saúde; 2009.

10. Ministério da Saúde (Brasil). Secretaria de Atenção à Saúde. Área Técnica de Saúde da Criança e Aleitamento Materno. Gestões e gestores de políticas públicas de atenção à saúde da criança: 70 anos de história. Brasília: Ministério da Saúde; 2011.

11. Sousa LB, Pinheiro AKB. Characterization of the Brazilian Production of Educational Videos on STD/HIV/Aids. Rev Enferm UFPI [internet]. 2012 Sep [Cited 2014 Mar 8] 1(3). Available from:http://revistas.ufpi.br/index.php/reufpi/ article/view/804/pdf_1

12. Comodo CN, Prette AD, Prette ZAPD, Manólio CL. O passeio de Bia (vídeo): apresentação e validade interna e externa de um recurso para a promoção de habilidades sociais de pré-escolares. Psicologia:Teoria e Prática. 2011 [Cited 2014 Mar 8] 13(1).

13. Alves, L.D. Avaliação dos vídeos educativos utilizados para promoção da saúde da criança. [Monografia] - Fortaleza: Universidade Federal do Ceará; 2013. [Cited 2014 Fev 28].

14. Bandura, A. Self-efficacy: toward a unifying theory of behavioral change. Psychological Review. 1977[cited 2013 Jan 1]; 84 (2).

15. Liu, J. Maternal beliefs and behaviors in the prevention of childhood diarrhea in Dar es Salaam, Tanzania. 2009. 104f. [thesis] [internet] Stanford: Stanford University Press; 2009. [cited 2012 may 18] Available from: https://studentaffairs.stanford.edu/sites/default/files/haas/files/Jessie\%20 Liu\%20Thesis.pdf.

16. Rondelli, E. Mídia e saúde: os discursos se entrelaçam. In: Pitta AMR, organizador. Saúde \& Comunicação: visibilidades e silêncios. São Paulo: Hucitec; Rio de janeiro: Abrasco. 1995. p. 38-34. 
17. Bernardi JR, Gama CM, Vitolo MR. An infant feeding update program at healthcare centers and its impact on breastfeeding and morbidity. Cad. Saúde Pública [internet]. 2011 June [cited 2013 July 08] ; 27(6): 1213-1222. Available from:http:// www.scielosp.org/scielo.php?script=sci_ar ttext\&pid=S0102311X2011000600018\&lng =en. DOI: http://dx.doi.org/10.1590/S0102$-311 \times 2011000600018$.

18. Queiroz PH, Shimo AK, Nozawa MR. Primary health care's nurses in the promotion of breastfeeding. R. pesq.: cuid. fundam. [internet] 2011 Apr [cited 2014 Mar 8] 3(2). Available from: http:// web.a.ebscohost.com/abstract?direct=true\&pro file=ehost $\&$ scope $=$ site \&authtype $=$ crawler $\&$ jrnl $=$ $21755361 \& A N=69933797 \& \mathrm{~h}=4 \% 2 \mathrm{fm} \times z 3 D B h N$ xFsuOWVDsjYrrja60ImMXCTwSEktIEbj40hKf\%2 fi170WF7urNeV8kbV1nPcH\%2bQ7xoGLBqyXo $\mathrm{kCeg} \% 3 \mathrm{~d} \% 3 \mathrm{~d} \& \mathrm{crl}=\mathrm{c}$

19. Vranjac A. Vaccine against rotavirus. Revista de Saúde Pública [internet]. 2006 Apr [cited 2014 Mar 8] 40 (2). Available from: http://www.scielo. br/scielo.php?script=sci_arttext\&pid=S0034$-89102006000200026 \&$ lng $=p t \& n r m=i s o \& t / n$ g=pt. DOI: http://dx.doi.org/10.1590/S003489102006000200026

20. Oliveira JSA, Carneiro AMMA, Patriota EF, Gomes MGCGP, Medeiros SM, Fernandes, SMBA. Prevention of infantile diarrhea: Integrative literatura review. Journal of Nursing. 2012 [Cited 2014 Mar 8]; 6 (5).
All the authors participated in the phases of this publication in one or more of the following steps, in accordance with the recommendations of the International Committee of Medical Journal Editors (ICMJE, 2013): (a) substantial involvement in the planning or preparation of the manuscript or the collection, analysis or interpretation of data; (b) preparing the work or performing critical review of the intellectual content; (c) approval of the version submitted. All the authors declare to the proper purposes they are responsible for the content related to all aspects of the manuscript submitted to OBJN content. They assure that any issues related to the accuracy or completeness of any part of the article have been properly investigated and resolved, excluding therefore the OBJN from any joint participation in any imbroglios on the matter at hand. All authors declare that they have no conflict of interest, whether financial or personal, to influence the interpretation and/or recording of the findings. This statement was digitally signed by all the authors as recommended by the ICMJE which provides a model available in http://www.objnursing.uff.br/normas/ DUDE_final_13-06-2013.pdf

Received: 03/22/ 2014
Revised: 08/27/2014
Approved: 09/08/2014 